\title{
Soft tissue injury resulting from falling predicts a future major falling injury in the home dwelling elderly
}

\author{
Mika Herala, Heikki Luukinen, Risto Honkanen, Keijo Koski, Pekka Laippala, \\ Sirkka-Liisa Kivelä
}

\begin{abstract}
Department of Public
Health Science and

General Practice,

University of Oulu,

Unit of General

Practice, Oulu

University Hospital,

PO Box 5000,

FIN-90401, Oulu,

Finland

M Herala

H Luukinen

K Koski

S-L Kivelä
\end{abstract}

Tampere School of Public Health,

University of Tampere

and Tampere

University Hospital,

Tampere, Finland

P Laippala

Research Institute of Public Health,

University of Kuopio, Kuopio, Finland

R Honkanen

Correspondence to:

Dr Herala

(Mika.Herala@Oulu.fi)

Accepted for publication

22 February 2000

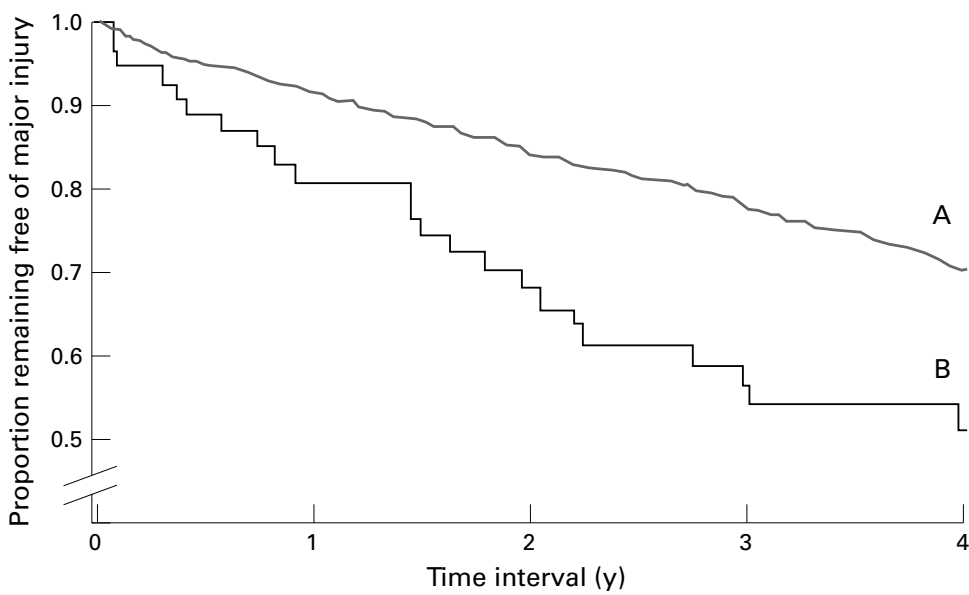

Figure 1 Kaplan-Meier curves for major fall injuries over four years. Curve A represents the elderly without a previous major fall injury $(n=658)$, and curve $B$ represents the elderly who had a previous fall with serious soft tissue injury $(n=57)$. tory of falls are likely to sustain subsequent falls and injurious falls. ${ }^{1}$ Elderly people who have had a previous fall with a fracture are at an increased risk of major injurious fall. ${ }^{2}$ However, the recurrence of major fall injuries other than fractures remains unknown. We conducted a prospective population-based cohort study among home dwelling elderly people to examine the risk of major injurious falls associated with a previous fall with serious soft tissue injury.

\section{Methods and results}

We recorded all falls according to ICD-9, 9th revision, (E880A-E899A) among all home living persons aged 70 years or over and resident in five rural municipalities in northern Finland on 1 January 1991. Fall recording from 1 January 1991 until 31 December 1996, was based on telephone contacts every third month and annual examination of the medical records. A major injury associated with a fall was a fracture, joint dislocation, wound needing suturing or other serious soft tissue injury. ${ }^{23}$ Participants who sustained a fracture because of a fall $(n=33)$ in 1991 or 1992 , were excluded from the analyses. The risk of a major injurious fall in 1993-1996 as regards the occurrence of a fall with serious soft tissue injury in 1991 or
Community dwelling elderly people with a his-

The independent predictors of major injurious fall were previous soft tissue injury (HR (hazard ratio) $2.1,95 \%$ CI 1.32, 3.26), dependency as regards at least one ADL (HR 1.8, 95\% CI 1.10, 3.07), reduced visual acuity (HR 1.6, $95 \%$ CI $1.06,2.30$ ), female sex (HR 1.5, 95\% CI 1.07, 2.08) and diabetes (HR 1.5, $95 \% \mathrm{CI}$ $1.02,2.09)$. The total number of falls was protective (HR for one fall 0.9 95\% CI 0.836, 0.999). When the participants with fracture outcome were excluded from the analyses, the predictive value of a previous soft tissue injury was 2.6 (95\% CI 1.55, 4.52). To assess the contribution of environmental factors on the risk of major injurious fall we repeated analyses separately for falls occurring indoors and outdoors. Adjusted HR for major injurious fall occurring indoors as regards previous serious soft tissue injury was 1.6 (95\% CI $0.87,2.93)$ 
and that of major injurious fall occurring outdoors was 3.6 (95\% CI 1.73, 7.44).

\section{Comment}

Our results suggest that, in addition to falls and fractures, serious soft tissue injury also predicts future major injurious falls independently of several subject related risk factors for major injurious falls. This prediction concerns especially major injurious falls occurring outdoors, suggesting contribution of environmental factors. Physicians treating older patients with soft tissue injuries should take effective measures to prevent future major falling injuries in these persons.
Funding: this study was supported by the Juho Vainio Foundation.

Conflicts of interest: none.

1 O'Loughlin JL, Robitaille Y, Boivin J-F, et al. Incidence of and risk factors for falls and injurious falls among the community-dwelling elderly. Am F Epidemiol 1993;137: 342-54.

2 Nevitt MC, Cummings SR, Hudes ES. Risk factors for injurious falls: a prospective study. F Gerontol Med Sci 1991;46: M164-70.

3 Luukinen $\mathrm{H}$, Koski K, Honkanen R, et al. Incidence of injury-causing falls among older adults by place of residence: a population-based study. $\mathcal{F} \mathrm{Am}$ Geriatr Soc 1995;43:871-6.

4 Luukinen H, Koski K, Laippala P, et al. Factors predicting fractures during falling impacts among the home-dwelling elderly. F Am Geriatr Soc 1997;45:1302-9. 